\title{
FYN Gene
}

National Cancer Institute

\section{Source}

National Cancer Institute. FYN Gene. NCI Thesaurus. Code C18419.

This gene plays a role in the regulation of cell growth and proliferation. 